\title{
AKIBAT HUKUM TERHADAP JAMINAN KREDIT PEMILIKAN RUMAH YANG MASIH DALAM PROSES PEMECAHAN SERTIPIKAT
}

\author{
Ari Julianingsih ${ }^{1}$ \\ Program Studi Magister Kenotariatan \\ Fakultas Hukum \\ Universitas Narotama Surabaya \\ Email : julianingsih.ari81@gmail.com \\ Habib Adjie ${ }^{2}$ \\ Program Studi Magister Kenotariatan \\ Fakultas Hukum \\ Universitas Narotama Surabaya \\ Email :
}

\begin{abstract}
ABSTRAK
Penelitian ini bertujuan untuk mengetahui atau menganalisis Akibat Hukum akta Jaminan Kredit Pemilikan Rumah yaitu pada akta Surat Kuasa Membebankan Hak Tanggungan (SKMHT) yang diperpanjang terus menerus karena sertipikat yang dijadikan Jaminan Kredit Kepemilikan Rumah masih dalam proses pemecahan dimana perlindungan hukum bagi Kreditur Kredit Pemilikan Rumah terhadap Jaminan kredit yang proses pemecahan belum terpasang Hak Tanggungan, dengan menganalisa pembuatan Surat Kuasa Membebankan Hak Tanggungan yang dibuat dihadapan PPAT sesuai dengan ketentuan Undang-Undang Nomor 4 tahun 1996 tentang Hak Tanggungan, dimana banyak Notaris/Pejabat Pembuat Akta Tanah kurang memperhatikan peraturan Undang-Undang dengan membuat perpanjangan Surat Kuasa Membebankan Hak Tanggungan terus menerus tanpa mengadirkan kembali Pihak Pemilik Jaminan dan/atau Debitur dan Pihak Kreditur sehingga mengandung kecacatan dan tidak dapat dilakukan pembatan Akta Pemberian Hak Tanggungan. Dimana Notaris/PPAT pejabat yang bekerja sesuai permintaan/order dari Kreditur (Bank) bukan Pejabat Umum yang menjalankan tugasnya sesuai Peraturan Undang-undang yang berlaku, yang dapat memberikan perlindungan hukum terhadap Kreditur.
\end{abstract}

Kata Kunci : Jaminan, Surat Kuasa Membebankan Hak Tanggungan, Pemecahan, Perlindungan Hukum

\footnotetext{
${ }^{1}$ Mahasiswa Fakultas Hukum Narotama

${ }^{2}$ Dosen Fakultas Hukum Narotama
} 


\section{A. PENDAHULUAN}

\section{Latar Belakang Masalah}

Kredit Pemilikan Rumah saat ini banyak dibutuhkan oleh masyarakat Indonesia terutama pada kota-kota yang sedang berkembang. Kredit Pemilikan Rumah adalah kredit yang digunakan untuk membeli rumah atau kebutuhan konsumtif lainnya dengan jaminan/agunan berupa rumah yang akan dibeli oleh debitur.

Pengembang (developer) adalah pembangun perumahan baik perorangan maupun perusahaan yang bergerak di bidang property, baik itu berupa perumahan dalam skala besar maupun kecil. pengembang untuk mengembangkan usahanya bekerja sama dengan bank untuk menjual tanah yang dipecah/dikavling yang siap dibangun perumahanperumahan. Pemasarannya selain dipasarkan oleh developer pihak bank juga memasarkan karena tujuan bank memasarkan untuk mencari Debitur. Bank merupakan lembaga keuangan yang mempunyai peranan penting dalam mendukung pertumbuhan ekonomi nasional dan merupakan sarana bagi pemerintah dalam menggalakkan pembangunan, khususnya dibidang material melalui kegiatan perkreditan ${ }^{3}$.

Debitur Kredit pemilikan rumah yang obyek rumahnya diperoleh dari developer, biasanya developer menyarankan mengambil Kredit pemilikan rumah tersebut pada bank yang telah bekerja sama dengan developer, Bentuk kerja sama antara pengembang (developer) dengan bank dilakukan dengan cara pertama-tama pengembang menjadi debitur Bank, karena pengembang (developer) dalam membangun perumahan-perumahan tersebut membutuhkan modal yang sangat besar dengan menjadikan jaminan tanah-tanah Sertipikat Hak Atas Tanah yang rencana dipecah/dikavling untuk dijual per-unit kepada user/calon Debitur. Salah satunya dalam hai ini kredit yang diberikan oleh pihak bank kepada developer adalah Kredit Modal Kerja karena dengan tujuan dijual kembali dalam bentuk cicilan Kredit Pemilik Rumah. Dengan agunan sertipikat tanah yang akan dipecah dan selanjutnya akan di jual belikan secara tunai maupun Kredit. Pembanguan perumahan dapat dibiayai dengan kredit korporasi dengan jaminan seluruh bagunan rumah yang ada yang diikat dengan Hak Tanggungan, sedangkan pembelian rumah dapat

\footnotetext{
3 Achmad Anwari, Bank Rekan Terpercaya dalam Usaha Anda, cetakan Pertama, Balai Aksara, Jakarta, 1981, hlm. 15
} 
dibiayai dengan kredit Konsumer, dengan jaminan berupa rumah yang dibeli. Jika masyarakat hendak membeli dengan memperoleh fasilitas kredit dari bank, maka setelah akta jual beli dibuat, selanjutnya dana dari bank tersebut dibayarkan kepada pemberi fasilitas kredit korporasi. ${ }^{4}$ Fasilitas kredit perumahan yang diberikan mempunyai risiko yang disebabkan oleh berbagai alasan. Bank wajib mempunyai keyakinan berdasarkan analisis yang cermat atas itikad baik dan kemampuan serta kesanggupan debitur dalam melunasi hutangnya/mengembalikan pembiayaan yang dimaksud sesuai dengan yang telah diperjanjian.

Jaminan yang berupa tanah diatur dalam Undang-Undang nomor 4 tahun 1996, tentang Hak Tanggungan atas tanah beserta benda-benda yang berkaitan dengan tanah. Menurut pasal 1 UndangUndang Hak Tanggungan nomor 4 tahun 1996, menyatakan bahwa Hak Tanggungan adalah Hak Jaminan yang dibebankan pada hak atas tanah sebagaimana dimaksud dalam UndangUndang Nomor 5 tahun 1960 tentang peraturan Dasar Pokok-Pokok Agraria, berikut atau tidak berikut benda-benda lain

${ }^{4}$ Tri Widiyono, Anggaran Kredit Dalam Finansial Engineering, Ghalia Indonesia, Jakarta, 2009, hlm 55. yang merupakan satu kesatuan dengan tanah itu, untuk pelunasan hutang tertentu, yang memberikan kedudukan yang diutamakan kepada kreditur tertentu terhadap kredit-kredit lain.

Jaminan dalam bentuk tanah mempunyai mekanisme tersendiri, dimana berdasarkan prosedur tata cara yang sudah ada maka tanah yang dijadikan jaminan Bank harus dipasang Hak Tanggungan terlebih dahulu. Untuk memasang Hak Tanggungan tersebut ada beberapa tahapan yaitu dimulai dengan dibuatnya perjanjian pokok berupa perjanjian kredit atau pengakuan hutang atau perjanjian lain yang menimbulkan hubungan pinjam meminjam uang antara Kreditur (Bank) dengan Debitur. Sesuai dengan sifat Hak Tanggungan yaitu accesoir bahwa pemberiannya haruslah merupakan ikutan dari perjanjian pokok.

Setelah perjanjian pokok ditandatangani maka tahap selanjutnya yaitu pembebanan Hak Tanggungan yang ditandai dengan pembuatan Akta Pemberian Hak Tanggungan (APHT), apabila ada syarat-syarat yang belum terpenuhi dalam pembuatan Akta Pemberian Hak Tanggungan, dalam hal sertipikat yang menjadi jaminan masih dalam proses Penggapusan Hak Tanggungan yang biasa disebut roya, peningkatan Hak, Peralihan dan 
pemecahan pada Kantor Badan

Pertanahan. Apabila tidak memungkinkan untuk pengikatan dengan Hak Tanggungan (APHT) maka akan dijembatani dengan menggunakan Akta Surat Kuasa Membebankan Hak Tanggungan (untuk selanjutnya disingkat SKMHT) terlebih dahulu, yang berbentuk Akta autentik yang dibuat dihadapan Notaris atau Pejabat Pembuat Akta Tanah (PPAT).

Dalam SKMHT pemilik sertipikat (pemegang hak) memberi kuasa kepada pihak kreditur (penerima kuasa) untuk membebankan Hak Tanggungan diatas Hak Atas Tanahnya. Namun dalam prakteknya kredit modal kerja yang diberikan oleh pihak bank kepada pengembang (developer), Agunan kredit tersebut tidak dipasang Hak Tanggungan, karena alasan akan dijual kembali setelah dilakukan pemecahan, sehingga Notaris/PPAT melakukan pembuatan SKMHT yang diperpanjang terus menerus sampai proses pemecahan selesai, sedangkan dalam sertipikat tersebut setelah dipecah nomor hak akan berubah sesuai dengan jumlah yang dipecah, alasan pengembang dalam hal ini sudah mempunyai daftar calon pembeli secara tunai atau kredit, karena sebelumnya pengembang (developer) dan bank sudah mempunyai perjanjian bekerja sama bahwa bank akan membiayai calon pembeli (user). Penggunaan SKMHT menjadi APHT dalam proses pemecahan inilah yang banyak mengalami hambatan, karena lamanya proses pemecahan hak atas tanah melebihi batas waktu SKMHT yang ditentuan Undang-Undang, Sehingga SKMHT tidak dapat terpasangnya APHT. Dalam praktek sering terjadi bahwa perbuatan yang dibuatkan aktanya akan merugikan pihak lain atau setidaknya langsung maupun tidak langsung akan merugikan pihak lain. ${ }^{5}$

\section{Rumusan Masalah}

Berdasarkan latar belakang permasalahan diuraikan diatas, selanjutnya rumusan permasalahan yang akan diteliti adalah sebagai berikut :

1. Apa Akibat Hukum terhadap akta SKMHT yang diperpanjang terus menerus karena Jaminan Kredit (KPR) dalam proses pemecahan ?

2. Apakah perlindungan hukum bagi Kreditur terhadap Jaminan kredit yang proses pemecahan belum terpasang Hak Tanggungan?

\footnotetext{
${ }^{5}$ Habib Adjie, Tebar Pemikiran 2 Dalam dunia Notaris \&PPAT , Lembaga Kajian Notaris\&PPAT Indonesia, Surabaya 2003, hlm 32 .
} 


\section{Tujuan Penelitian}

Penelitian harus mempunyai tujuan yang jelas, adapun tujuan yang ingin dicapai dalam penelitian ini adalah :

1. Untuk menganalisis Akibat Hukum terhadap akta SKMHT yang diperpanjang terus-menerus karena Jaminan Kredit (KPR) dalam proses pemecahan.

2. Untuk menganalisis perlindungan hukum bagi Kreditur terhadap Jaminan kredit yang proses pemecahan belum terpasang Hak Tanggungan.

\section{Manfaat Penelitian}

\subsection{Manfaat Teoritis}

a. Mengembangkan ilmu hukum yang memberikan analisis tentang Jaminan Kredit Kepemilikan Rumah, Akibat hukum, kepastian hukum terhadap Akta-akta Jaminan Kredit yang masih proses pemecahan di BPN.

b. Penelitian ini berguna untuk menambah ilmu hukum yang berkaitan dengan perlindungan hukum bagi Kreditur/Bank terhadap jaminan kredit masih proses pemecahan sehingga belum terpasang Hak Tanggungan.

\subsection{Manfaat Praktis}

a. Penelitian ini diharapkan dapat memberikan masukan kepada kreditur dalam pemberian Fasilitas kredit pemilikan rumah (KPR) harus ada kepastian hukum terhadap jaminan kredit yang dijadikan agunan.

b. Memberikan sumbangan pemikiran bagi Notaris/PPAT agar dapat digunakan sebagai dasar dalam pembuatan aktaakta Jaminan seperti SKMHT, APHT atau akta-akta lain yang terkait dengan jaminan kredit pemilikan rumah (KPR) yang masih dalam proses pengurusan pemecahan di BPN. 


\section{B. Metode Penelitian}

\section{Tipe Penelitian}

Penelitian yang dilakukan adalah penelitian hukum normatif (Normative legal Research), yaitu penelitian yang dilakukan dengan cara mengkaji peraturan perundang-undangan yang berlaku atau diterapkan terhadap suatu permasalahan tertentu. Pada penelitian hukum normatif, bahan pusaka merupakan bahan hukum sekunder yang mempunyai ruang lingkup yang sangat luas, bahan hukum sekunder sebagai pendukung bahan hukum primer berupa peraturan perundang-undangan. dengan adanya bahan hukum sekunder tersebut, seorang peneliti tidak perlu mengadakan penelitian secara langsung terhadap faktor-faktor yang menjadi latar belakang penelitian sendiri.

Seorang peneliti harus bersifat kritis karena peneliti tidak boleh terpengaruh oleh jalan pemikiran peneliti liannya, karena akan berpengaruh pada pemikiran yang digunakan dalam penelitiannya sendiri.

\section{Pendekatan Masalah}

Dalam Penelitian ini menggunakan tiga metode pendekatan masalah yaitu :

1. Pendekatan Undang-undang (statue Approach) dilakukan dengan menelaah semua peraturan perundangundangan yang bersangkut paut dengan isu hukum yang sedang dihadapi, pendekatan perundangundangan ini dilakukan oleh peneliti untuk kegiatan praktis untuk mempelajari antara undang-undand satu dengan undan-undang yang lain. Dan bagi peneliti juga untuk kegiatan akademis , peneliti perlu mencari ratio legis dan dasar otnologis suatu Undang-undang, sehingga peneliti akan dapat menyimpulkan mengenai ada tidaknya antara undang-undang dengan isu hukum yang dihadapi.

2. Pendekatan Konseptual (conceptual Approach), yaitu pendekatan yang beranjak dari pandangan-pandangan dan doktrin-doktrin yang berkembang didalam ilmu hukum. Pendekatan ini menjadi penting sebab pemandangan terhadap pandangan/doktrin yang berkembang dalam ilmu hukum dapat menjadi pijakan untuk membangun argumentasi hukum ketika menyelesaikan isu hukum yang dihadapi. Pandangan/doktrin akan memperjelas ide-ide dengan 
memberikan pengertian hukum, konsep hukum, maupun asas hukum yang relevan dengan permasalahan.

\section{Sumber Bahan Hukum}

Dalam penelitian yuridis normatif ini menggunakan bahan hukum primer dan bahan hukum sekunder yang diperoleh dari perpustakaan. Adapun sumber bahan hukum dalam penelitian ini adalah :

1. Bahan Hukum Primer

Bahan Hukum primer diperoleh dari Undang-undang yang terkait dengan pokok permasalahan yaitu :

a. Undang-undang Dasar Negara Republik Indonesia tahun 1945.

b. Undang-undang Nomor 5 Tahun 1960 tentang pokok-pokok Agraria.

c. Undang-undang Nomor 4 Tahun1996 tentang Hak Tanggungan beserta benda-benda yang berkaitan dengan tanah

d. Undang-undang nomor 10 t ahun 1998 tentang perubahan Undang-undang Nomor 7 tahun 1992 tentang perbankan.

e. Undang-undang Nomor 2 tahun 2014 tentang Jabatan Notaris

f. Peraturan Kepala Badan Pertanahan Nasional Republik Indonesia Nomor 1 Tahun 2006, tentang pelaksanaan Peraturan Pemerintah Nomor 73 Tahun 1998 Tentang Peraturan Jabatan Pejabat Pembuat Akta Tanah. g. Kitab Undang-undang Hukum Perdata.

2. Bahan Hukum Sekunder

Bahan Hukum Sekunder yaitu bahan hukum yang mendukung bahan hukum primer, yakni antara lain seperti artikel, tesis, disertasi, jurnal, dan hasilhasil penelitian atau pendapat sarjana atau ahli hukum yang memuat doktrin-doktrin para ahli hukum mengenai hukum perjanjian, hukum perbankan, hukum jaminan dan hukum Pertanahan.

\section{Teknik Pengumpulan dan}

\section{pengelolahan Bahan Hukum}

Setelah isu hukum ditetapkan, peneliti melakukan penelusuran untuk mencari bahan-bahan hukum primer dan bahan-bahan hukum sekunder yang relevan dengan isu hukum yang dikaji. Karena penelitian ini menggunakan pendekatan perundang-undangan (statute appoach), maka peneliti mencari peraturan perundang-undangan dalam hal ini meliputi "baik yang berupa legislation maupun regulation bahkan juga delegated legislation dan delegated regulation. ${ }^{6}$

Dari pengumpulan bahan hukum yang berupa perundang-undangan melalui pendekatan konseptual (conceptual approach), bahan perundang-undangan tersebut dikaitkan dengan buku-buku hukum dan didalamya terdapat pandangan

\footnotetext{
${ }^{6}$ Peter mahmud marzuki, Penelitian Hukum, Edisi Revisi, Kencana Prenada Media grup, jakarta, 2005, hlm 94
} 
dan doktrin-doktrin para ahli hukum khususnya dibidang hukum perjanjian, hukum pernbankan, hukum jaminan, dan hukum pertanahan, selanjutnya dikaitkan dengan pendekatan sejarah untuk mencari sejarah dalam pembentukan peraturan perundang-undangan dan kelembagaannya, sehingga peneliti akana menemukan ide-ide yang melahirkan pengertian-pengertian hukum yang relevan dengan isu yang dihadapi serta mampu menjawb isu yang dikaji.

\section{Analisis Bahan Hukum.}

Dalam tahap analisis bahan hukum, terlebih dahulu bahan hukum telah diperoleh akan diolah terlebih dahulu, kemudian dianalisis secara kualitatif dengan memperhatikan ketentuanketentuan hukum yang ada dan asas-asas hukum yang berkaitan dengan kaidah hukum yang berlaku sehingga menghasilkan uraian yang bersifat deskriptif kualitatif, yaitu suatu uraian yang sistemstis, logis, realistis yang menggambarkan permasalahan dan pemecahannya secara jelas dan lengkap berdasarkan bahan hukum yang diperoleh dari penelitian, dengan demikian akan dapat dijawab isu hukum yang dibahas.
C. PEMBAHASAN

1. Akibat Hukum terhadap akta SKMHT yang diperpanjang terus menerus karena Jaminan Kredit (KPR) dalam proses pemecahan

Tanah dan bangunan merupakan jaminan yang sangat penting dalam kredit, karena tanah dan bangunan mempunyai nilai ekonomis yang sangat tinggi, dalam penjaminan kredit berupa tanah diatur didalam UndangUndang nomor 4 tahun 1996, tentang Hak Tanggungan Atas Tanah Beserta Benda-Benda Yang Berkaitan Dengan Tanah. Menurut pasal 1 UndangUndang Hak Tanggungan nomor 4 tahun 1996, menyatakan bahwa Hak Tanggungan adalah Hak Jaminan yang dibebankan pada hak atas tanah sebagaimana dimaksud dalam UndangUndang Nomor 5 tahun 1960 tentang peraturan Dasar Pokok-Pokok Agraria, berikut atau tidak berikut benda-benda lain yang merupakan satu kesatuan dengan tanah itu, untuk pelunasan hutang tertentu, yang memberikan kedudukan yang diutamakan kepada kreditur tertentu terhadap kredit-kredit lain. Mekanisme dalam penjaminan menurut Undang-undang Hak Tanggungan Wajib untuk dipasang Hak Tanggungan, dalam hal ini peran Notaris/PPAT sangat penting dalam 
pembuatan Akta-akta jaminan terhadap

Tanah. PPAT menurut Peraturan Pemerintah nomor 37 tahun 1998 Pasal 1 adalah Pejabat Umum yang diberi kewenangan untuk membuat akta-akta otentik mengenai perbuatan hukum tertentu mengenai hak atas tanah atau Hak Milik Atas Satuan Rumah Susun. Sebutan Pejabat Umum (openbaar ambtenaar) biasanya dikaitkan dngan urusan pemerintahan, karena istilah openbaar berarti urusan yang terbuka untuk umum atau untuk kepentingan umum, urusan yang terbuka untuk umum meliputi semua bidang yang berkaitan dengan publik, sehingga mempunyai karakter khusus selalu dalam kerangka hukum publik. $^{7}$

SKMHT merupakan Akta Kuasa yang diberikan pemilik sertipikat (pemegang hak) memberi kuasa kepada pihak kreditur (penerima kuasa) untuk membebankan Hak Tanggungan diatas Hak Atas Tanahnya. Dalam kredit konstruksi yang diberikan kepada pengembang dalam rangka Kredit Pemilikan Rumah yang dimaksud dalam Penjelasan (alinea ke 3) Pasal 15 ayat (4) UU No 4 Tahun 1996 tentang UUHT menegaskan bahwa : Ketentuan pada

\footnotetext{
${ }^{7}$ Rusdianto Sesung, Hukum\&Politik Hukum Jabatan Notaris, R.A.De.Rozarie 2017, hlm. 184.
}

ayat ini berlaku juga terhadap tanah yang sudah bersertipikat tetapi belum didaftar atas nama pemberi Hak Tanggungan sebagai pemegang hak batas tanah yang baru, yaitu tanah yang belum didaftarkan peralihan haknya, pemecahannya atau penggabunganya. Penjelasan (alinea ke 3) ini untuk tanah yang bersertipikat, tetapi belum terdaftar atas nama pemberi Hak Tanggungan, dengan alasan : Belum didaftarkan peralihan haknya, berupa : Jual Beli, Hibah, APHB, Warisan, Lelang. Dan masa berlakunya SKMHT selambat-lambatnya 3 (tiga) bulan harus diikuti dengan pembuatan APHT.

Jangka Waktu SKMHT yang sudah ditentukan Undang-undang Hak Tanggungan harus segera diikuti dengan pembuatan APHT, karena apabila jangka waktu SKMHT yang telah ditentukan telah habis, maka akta SKMHT akan gugur dengan sendirinya, dalam kredit Pemilikan Rumah sertipikat yang dijadikan Jaminan kebanyakan masih dalam proses pemecahan, karena Sertipikat yang dilakukan pemecahan oleh pengembang melalui beberapa proses yaitu penurunan hak apabila sertipikat yang dibebaskan pengembang berasal dari Hak Milik, dan Ijin Peruntukkan Penggunaan Tanah (IPPT) apabila tanah berubah 
peruntukkanya dari tanah perkarangan dan pertanian menjadi perumahan. Proses ini membutuhkan waktu kurang lebih 6 bulan, sehingga sertipikat yang akan dijadikan jaminan kredit oleh pengembang berupa akta SKMHT akan gugur jangka waktunya, sehingga sering dilakukan perpanjangan SKMHT terus-menerus sampai proses pemecahan selesai. PPAT dalam perpanjangan SKMHT harus menghadirkan Debitur atau selaku pemegang Hak dan Kreditur selaku Bank untuk melakukan penandatanganan SKMHT. Apabila PPAT tidak menghadirkan Debitur dan Kreditur dalam perpanjangan SKMHT akan tetapi dengan mencadangkan SKMHT yang telah ditandatangani pada saat pertama pengikatan Kredit maka SKMHT yang dibuat dihadapan PPAT tersebut akan batal demi hukum dan SKMHT yang diperpanjang akan menjadi terdegradasi menjadi akta dibawah tangan. Karena menyalagunakan kewenangan dalam pembuatan Akta PPAT.

Fungsi dan tanggung jawab PPAT serta tanggung jawab pertanahan beranjak dari sistem publikasi negatif dan kewajiban menilai dokumen, maka sebaiknya terdapat pembagian fungsi dan tanggung jawab antar PPAT dan petugas pendaftaran PPAT dalam fungsi dan tanggung jawabnya yaitu:
1. Membuat akta yang dapat dipakai sebagai dasar yang kuat bagi pelaksanaan pendaftaran peralihan hak atau pembebanan hak.

2. PPAT bertanggung jawab terhadap terpenuhinya unsur kecakapan dan kewenangan penghadap dalam akta dan keabsahan perbuatan haknya sesuai data dan keterangan yang disampaikan kepada para penghadap yang dikenal atau diperkenalkan.

3. PPAT bertanggung jawab terhadap dokumen yang dipakai sebagai dasar melakukan tindakan hukum dari segi kekuatan dan pembuktiannya telah memenuhi jaminan kepastian untuk ditindaklanjuti dalam akta autentik dan sesuai dengan ketentuan yang berlaku.

4. PPAT bertanggung jawab atas sahnya perbuatan hukum sesuai data keterangan para penghadap serta menjamin keautentikan akta dan bertanggung jawab bahwa perbuatannya sesuai prosedur. ${ }^{8}$

Akibat hukum SKMHT yang diperpanjang terus menerus dimana jaminan kredit masih dalam proes pemecahan tidak diukuti dengan pembuatan APHT. Sebagaimana diatur dalam pasal 15 ayat 6 Undang-undang

\footnotetext{
${ }^{8}$ Rusdianto Sesung. "Prinsip kehati-hatian Pejabat

Pembuat Akta Tanah dalam Pengurusan

Peralihan Tanah Letter C."Al-Daulah Jurnal

Hukum dan Perundangan Islam, Volume 7,

Nomor 2, Oktober 2017: 451
} 
Nomor 4 Tahun 1996 tentang Hak Tanggungan atas tanah beserta bendaBenda yang berkaitan dengan Tanah, menyatakan bahwa SKMHT yang tidak dikuti dengan pembuatan APHT, dalam waktu yang ditentukan maka akan batal demi hukum, yang lebih tepat adalah dibatalkan, dimana pembatalan itu diadakan karena perbuatan tersebut merupakan suatu kekurangan karena berdasarkan tata cara pendaftaran Hak Tanggungan setelah membuat SKMHT harus segera diikuti APHT.

Akibatnya untuk kepentingan pihak debitur maka SKMHT harus diperpanjang terus-menerus, sehingga dibutuhkan waktu dan biaya yang dibebankan kepada debitur untuk pembuatan SKMHT perpanjangan tersebut dihadapan Notaris/PPAT. Sedangkan untuk pihak kreditur karena apabila debitur kreditur merupakan kewajiban bagi kreditur sebelum jangka waktu SKMHT berakhir segera ditindak lanjuti pembuatan APHT oleh PPAT, dan apabila lalai dan terjadi kredit Macet maka kreditur tidak mempunyai Hak eksekutorial terhadap jaminan tersebut. Dan bagi debitur ketentuan batas SKMHT yang sangat singkat, maka debitur akan diminta kreditur untuk memperpanjang SKMHT sebelum Jangka Waktunya berakhir, dengan biaya pembuatan perpanjangan SKMHT yang dibebankan Kepada Pihak Debitur.

Ketentuan batas waktu SKMHT apabila sertipikat yang dijadikan jaminan masih dalam proses pemecahan membawa konsekwensi terhadap kreditur maupun debitur, untuk kreditur merupakan kewajiban bagi kreditur sebelum jangka waktu SKMHT berakhir segera ditindak lanjuti pembuatan APHT oleh PPAT, dan apabila lalai dan terjadi kredit Macet maka kreditur tidak mempunyai Hak eksekutorial terhadap jaminan tersebut. Dan bagi debitur ketentuan batas SKMHT yang sangat singkat, maka debitur akan diminta kreditur untuk memperpanjang SKMHT sebelum Jangka Waktunya berakhir, dengan biaya pembuatan perpanjangan SKMHT yang dibebankan Kepada Pihak Debitur.

Perkaban 8/2012 wajib tunduk pada ketentuan UUJN jo UUJNP serta peraturan perundang-undangan lain seperti Pasal 1868 KUHPerdata agar SKMHT dapat dinyatakan sebagai akta otentik. Keotentikan suatu akta notaris didasari oleh Pasal 1868 KUHPerdata dengan syarat - syarat sebagai berikut $:^{9}$

\footnotetext{
${ }^{9}$ Habib Adjie, 2009, Meneropong Khazanah Notaris dan PPAT Indonesia (Kumpulan Tulisan Tentang Notaris dan PPAT), PT. Citra Aditya Bakti, Bandung, hlm 32
} 


\section{[UNIVERSITAS MATARAM]}

a. Akta itu harus dibuat oleh ( door) atau dihadapan ( ten over $s$ taan) seorang pejabat umum ;

b. Akta itu harus dibuat dalam bentuk yang di tentukan oleh undang-undang ;

c. Pejabat umum oleh atau dihadapan siapa akta itu dibuat harus mempunyai wewenang untuk membuat akta tersebut ;

\section{Bentuk perlindungan hukum bagi} Kreditur terhadap Jaminan kredit yang proses pemecahan belum terpasang Hak

\section{Tanggungan}

Minimnya pengaturan praktek pemasangan Hak Tanggungan terhadap terhadap jaminan sertipikat induk yang akan dipecah, sehingga dapat menyebabkan kerugian pada kreditur/Bank apabila debitur wanprestasi, hal ini ditunjuk dengan :

1. Adanya asas kepercayaan yang diberikan kreditur kepada Debitur

Dalam hal ini kreditur akan memberikan dana terlebih dahulu kepada developer untuk kredit pemilikan rumah, sehingga kreditur tidak memegang jaminan apapun karena sertipikat masih dalam proses pemecahan. Sehingga kreditur/bank hanya memberikan kepercayaan kepada debitur akan kemampuannya untuk mengembalikan kredit yang telah diperoleh. Maka dalam mengatasi hal ini kreditur bisa meminta kepada Notaris untuk membuat akta Perjanjian Penyerahan Jaminan dan Pemberian Kuasa (PPJPK).

2. Lemahnya eksekusi terhadap jaminan sertipikat induk yng masih dalam proses pemecahan

Sertipikat yang dijadikan jaminan kredit yang belum diikat APHT mempunyai resiko yang cukup besar apabila debitur wanprestasi sehingga bank tidak dapat mengeksekusi jaminan milik debitur yang masih proses pemecahan.

Notaris/PPAT dalam hal ini mempunyai peran yang sangat penting dalam memberikan perlindungan kepada Kreditur, dengan membuat akta jaminan kredit Pemilikan rumah yang masih proses pemecahan sesuai dengan peraturan perundang-undangan yang berlaku, apabila jatuh tempo pada akta jaminan yaitu SKMHT yang dibuatnya dan proses pemecahan sertipikat belum selesai maka Notaris/PPAT wajib menghadirkan kembali Debitur dan Kreditur untuk perpanjangan SKMHT tersebut sampai sertipikat proses pemecahan selesai dan bank selaku kreditur akan melanjutkan dengan memproses kredit pemilikan rumah kepada user/atau calon debitur yang sudah memberikan uang muka kepada developer. dengan menghadirkan kembali pihak developer sebagai pemegang sertipikat yang sudah pemecahan 
pembeli/debitur KPR dengan pembuatan Akta Jual Beli dan disertai dengan SKMHT antara pembeli/debitur KPR dengan Bank, apabila balik nama selesai bisa dilanjutkan dengan pembuatan APHT tidak perlu menghadirkan kembali debitur selaku pemegang hak, karena sudah terdapat kuasa yang diatur didalam Undang-undang nomor 4 tahun 1996 tentang Hak Tanggungan yang akan diwakili pihak Kreditur/Bank yang diberikan kuasa oleh pemberi Hak dan/debitur, dengan jangka waktu tujuh hari segera dilakukan pendaftaran Hak Tanggungan Pada Badan Pertanahan Nasional setempat untuk memenuhi azas publisitas. Sehingga Kreditur mempunyai Hak eksekusi apabila Debitur mengalami kemacetan kredit.

\section{Kesimpulan dan Saran}

SKMHT yang diperpanjang terus menerus dengan tidak mengadirkan Pihak Debitur dan/atau Pemberi Hak dan Pihak Kreditur dan/atau Penerima Hak, oleh Pejabat Pembuat Akta Tanah (PPAT) merupakan suatu pelanggaran terhadap peraturan Perundang-undangan maka akan merugikan bagi Pihak Kreditur karena Jaminan kredit tersebut tidak dapat terpasang Hak Tanggungan sehingga tidak mempunyai Hak eksekutorial.
Notaris/Pejabat Pembuat Akta Tanah wajib dapat memberikan perlindungan kepada kreditur dengan membuat akta jaminan sesuai dengan Undang-undang nomor 4 tahun 1996 tentang Hak Tanggungan, tidak dengan mencadangan pada saat awal pengikatan kredit yaitu pada saat penandatanganan Perjanjian Kredit dan Jaminan Kredit/SKMHT tanpa menghadirkan lagi Pihak Debitur dan Kreditur, karena hal ini sangat merugikan bagi pihak Kreditur apabila Debitur Macet.

Diharapkan untuk kedepannya Undang-undang Nomor 4 tahun 1994 tentang Hak Tanggungan Atas Tanah Beserta Benda-Benda yang berkaitan Dengan Tanah mengatur khusus pasal tertentu tentang perlindungan terhadap bank selaku kreditur apabila jaminan kredit debitur belum terpasang hak tanggungan dikarenakan adanya proses pemecahan sertipikat.

\section{DAFTAR PUSTAKA}

\section{Buku}

Ahcmad Anwar, Bank Rekan Terpercaya dalam Usaha Anda, cetakan pertama, Balai Aksara, Jakarta, 1981.

Tri Widiyono, Anggara Kredit Dalam Finansial Engineering, Ghalia Indonesia, Jakarta, 2009.

Habib Adjie, Tebar Pemikiran 2 Dalam dunia Notaris \&PPAT, Lembaga 
Kajian Notaris\&PPAT Indonesia,

Surabaya 2003

Peter mahmud marzuki, Penelitian

Hukum, Edisi Revisi, Kencana Prenada

Media grup, jakarta, 2005.

Rusdianto Sesung, Hukum\&Politik

Hukum Jabatan Notaris,

R.A.De.Rozarie 2017.

Habib Adjie, 2009, Meneropong

Khazanah Notaris dan PPAT Indonesia

(Kumpulan Tulisan Tentang Notaris

dan PPAT), PT. Citra Aditya Bakti,

Bandung

\section{Internet}

Rusdianto Sesung. "Prinsip kehati-hatian

Pejabat Pembuat Akta Tanah dalam

Pengurusan Peralihan Tanah Letter

C."Al-Daulah Jurnal Hukum dan

Perundangan Islam, 2017, 7.2, 444-465. 